\title{
THE PROBLEM BASED LEARNING THEMATIC INTEGRATIVE MODELS TO INCREASE CLASS MANAGEMENT FOR TEACHERS IN ELEMENTARY SCHOOL
}

\author{
Nurrohmatul Amaliyah* \\ Teacher Training and Education University of Muhammadiyah Prof. Dr. HAMKA \\ Jl. Limau II, Jakarta,Indonesia, nurramaliyah@uhamka.ac.id
}

\begin{abstract}
Meaningful learning for a teacher is when it can be understood that the knowledge provided to learners and their changes in the results obtained in the study. As one example of such learning is by using problem based learning thematic integrative. Problem-based learning is a way to acquire the knowledge that combines aspects of cooperative learning and concentrating activities on group work, problem-solving skills and independent learning, as well as discovering the importance of inter-disciplinary knowledge to understand the problem. This learning involves students to solve a problem through the stages of the scientific method so that students can learn the knowledge based on the issues and have the skills to solve problems. While the function of learning with Problem Based Learning method: (1). Learners will increase their problem-solving skills; (2). It's easier to remember; (3). Increased understanding; (4). Increased knowledge relevant to the world of practice; (5). Developing the leadership skills, teamwork, learning skills, and motivate learners. Therefore, this model is very useful for primary school teachers so expect an increase in management learning in the classroom.
\end{abstract}

Keywords: Problem Based Learning; Thematic Integrative; Improvement of Classroom Management

\section{INTRODUCTION}

The teacher is a milestone in any learning, particularly in the classroom, and as well as an elementary school teacher. In a classroom in the elementary school, the teacher role is very important. Therefore a teacher must have a science which is said to approach. Approach owned a primary school teacher is in the form of management approaches in the classroom. Learning will be more meaningful when done with good management. Similarly, primary school teachers, who every day are always dealing with students who are different from one individual to another individual, resulting in if you want to start the lesson the teacher has to deal with a variety of unfavorable situation. It is a challenge for teachers to be able to master classes with well.
A good class is a place of learning in which there are students with different backgrounds, character, personality, behavior and emotions are different. This will give effect to the teachers in implementing the learning process in the classroom, which in principle teachers hold two control at the same time in the classroom, in the form of teaching and management in the classroom. Problems related to the teaching of any effort to assist students in achieving the learning objectives, while management issues related to the effort to create and maintain conditions such that the learning process can take place effectively and efficiently in order to achieve the learning objectives.

Have often heard complaints students how hard they follow the load of school. They demanded to know everything that is demanded by the 
curriculum. Although his intellectual capacity can reach the load, students like regardless of his world. Yet they face must be solved on their own. Therefore, education must equip them with skills that can be used to overcome the problems they face. The capability is the ability to solve problems. This ability can be developed through learning where the problems presented in class and the students were asked to complete with all the knowledge and skills they possess. Learning is no longer a "transfer of knowledge", but consciously develop students' potential through the ability of a more dynamic and applicable.

Based on this, teachers need to design learning that is able to evoke the students' potential in using thinking skills to solve problems. One approach to learning is what is called "Problem Based Learning (PBL)". This learning approach focused on the problems presented by teachers and students to resolve the issue with all their knowledge and skills from various sources can be obtained.

On the other hand, learning that is now emerging is an integrative thematic learning. Integrative thematic learning is learning more emphasis on students' involvement in the learning process actively in the learning process, so that students can gain direct experience and are trained to be able to find themselves a variety of knowledge they have acquired. Through direct experience students will understand the concepts they learn and connect with others who have understood the concept.

From the above phenomenon, with a mix of thematic integrative, the authors tried to design-based problem-based learning to the thematic integrative. So with problem-based learning is expected to provide an integrative thematic colors are more attractive to primary school students in learning.

\section{RESULTS AND DISCUSSION}

\section{Definition of Problem Based Learning}

The results of the International Conference on Engineering Education, problem-based learning is defined as:

Problem Based Learning is efficient way to acquire new knowledge. It combines aspects from cooperative learning and focuses on team work, problem solving skills and self directive studies as well as reveals the importance of interdisciplinary knowledge for the understanding of problems. (Rau Dar Chin:2004:1)

Exposure above can be interpreted as follows, namely: problem-based learning is a way to acquire the knowledge that combines aspects of cooperative learning and concentrating activities on group work, problem-solving skills and independent learning, as well as discovering the importance of interdisciplinary knowledge to understand the problem. In line with what was expressed "Problem Based Learning is any learning situation in the which the problem drives the learning." [1] that have meaning problembased learning is a learning situation in which problems became the starting point of learning.

Furthermore Barrow [2] revealed that the problems in the PBM is unstructured problems (ill-structure), or contextual and engaging (contextual and engaging), thus stimulating students to ask questions from a variety of perspectives. According to Slavin Another characteristic of PBM include the submission of questions to the problem, focusing on the linkages between disciplines, Authentic investigation, cooperation, and products or works to be exhibited.

Based on the above exposure can thus be inferred that the problem-based learning is a method that seeks to facilitate individual learning and group by placing issues related to knowledge as the core of the activities of learning so that students can build their knowledge by way of its own interest. 
The rapid changes in the development of science and technology and the economy in the demands that cannot be bargained again for new competencies such as the importance of mastering skills in critical thinking, problem solving, decision

making and working in teams. The demands so that eventually gave birth to a new understanding

towards education that puts education no

longer oriented to

provide educated with the answers to the problems that may be encountered in real life, but education should be understood as an adult to learning people who are immature, how do I find the answer to all the problems that it faces.

As revealed by [3] in the sentence "The ultimate goal of learning is not about finding the best answer to a question but rather to train the student to learn through the process of problem solving, i.e. thinking steps, research topics, development plans etc." the sentence above would have the sense that the fundamental purpose of education is not looking for the best answer to the problem but more to train students to learn through problem-solving process, the steps of thinking, researching the topic and develop a plan.

This understanding may change step by step has been carefully gives new color how should education be implemented especially in formal institutions as the major media outlets in print resources are scalable and can be controlled. From this point that apparently all aspects and components began renewed step by step so that informed a collection of components into a new paradigm of organization of education.

Paradigm change in education as a result of the moved puts the understanding of education implies the practice of learning in school, one of the forms of fact is by presenting a Problem-based learning model is a breakthrough that implemented by health education where students are not placed in a position of passive recipient but as active participants in the learning process. The following comparison table will be served the old paradigm of learning (teacher centered) and a new paradigm of learning (student Centered).

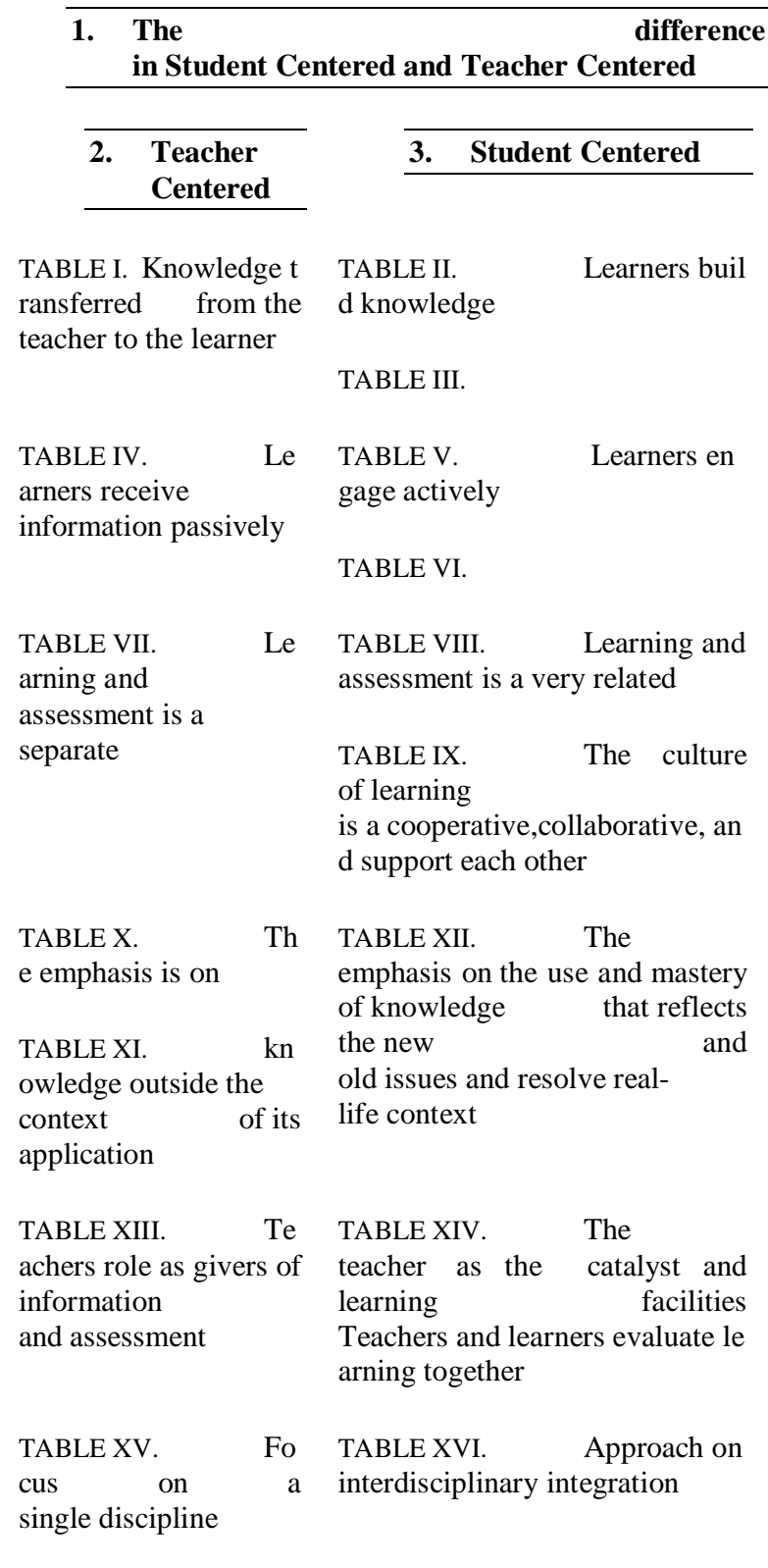

Source; Elsa. K \& Kamarza concept application of PBL training materials 2005 (m. Taufiq: 2009)

Based on the above exposure appears once the existence of a fundamental change of the role of teachers and students where the border wall be finished communications, has been lost with the fist role of students doing more learning in the process while the teacher is a facilitator and referring in the learning activities. The weakness that had 
been widespread now shifted bit by bit in learning to interpret.

Problem-based learning is a manifestation of the efforts of the new paradigm in the empowerment of students as learners there are three essential thingking the process of learning that should be a consideration has been reached. Namely as follows: first acquiring relevant knowledge (relevant knowledge) both thought to be able to understand (thinking) third doing (doing) the third it is reflected as a whole in model-based learning problems.

From the above it is clear that exposure to the PBM is in line with the idea of national education which brings orientation competency-based education. As part of the active learning method is a method of problembased learning, the most extensive since it combines the skills of thinking, real problems and working in groups.

Problem-based learning method (PBM) stem from the constructivism theory States that "Knowledge is not an absolute, but is rather constructed $b$ $y$ the learner based on previous knowledge and overall views of the world." Its meaning is not something absolute knowledge but constructe d by learners based on prior knowledge and views of the world.

The above statement can be translated as follows: constructivism suggests how knowledge should be compiled and assembled so that it can be studied, learning should be active because only students who can choose and interpret information from the environment. so constructivist confirms that understanding comes from interaction wit $h$ the environment, stimulating cognitive learning, conflict knowledge occurs when students negotiate in social situations, and assess individual understanding, problembased learning on the students have the opportunity to be build knowledge to their own, make a comparison with other students knowledge and refine their knowledge with experience.

From the above real exposure to that development is the Problem-based learning Method in existence of empirical theories, models or concepts that have been by the experts of the adherents of the flow of constructivism.

As for that being a special character of the problem-based learning method is:

a. Submission of the question or problem

Problem Based Learning method organizes teaching around the questions and issues that are both socially important and meaningful for the person.

\section{b. Focus on interdisciplinary linkages}

Problem Based Learning method may be based on one facet of the problem, but will be selected really real so that in solving them, students review from various establishments.

\section{c. Investigation of authentic}

Problem Based Learning method requires that students perform authentic investigation based on real problems with real resolution anyway.

\section{d. Generate product and flaunt it}

Problem

Based

Learning method demands students to produce a specific product in the form of real or paper artifacts and displays that describe or represent a form of settlement of the problems they find.

\section{e. Collaboration}

Problem Based Learning has a character the existence of methods of cooperation between the students either in pairs or in small groups. Working together provide motivation to continuously engage in complex tasks and give the opportunity of sharing discovery 
and dialogue to develop social skills and thinking skills.

TABLEI. Problem-based learning Method Benefits

As for the benefits that can be taken by applying the method of problem-based learning, Smith (2005) revealed that: the learners will increase the competence of solving the

problem, moreeasily remember, increased und erstanding, increased knowledge that is relevant to the world of practice, encouraging their full thoughts, build leadershi pskills and teamwork, learning skills, and motivate learners.

TABLE I. The method of Learningbased Thematic issue on Integrative Learning at elementary school

Learning in elementary school has undergone a redefinition as a centralized learning orientation shifted from master certain knowledge be mastere d skills to become learners. Problem based learning method is a form of response to the consequences of the shift paradigm of learning.

As for the application of the method-based thematic learning problems in integrative medicine in primary school is what is outlined by Richard Overbaugh:

Problem Based Learning is appropriate in the elementary school classroom (Katz \& Chard, 1989; Chard, 1998-a; Chard, 1998-b). Theoretically problem-based learning may lead to the use of a holistic approach and therefore is more beneficial to knowledge acquisition and transfer. In addition to involvement of real scenarios, problem-based learning requires that the "big picture" is laid out at the outset and subsequently students begin to work on parts. [4]

Exposure above has a meaning worthy issuebased learning implemented in elementary schools theoretically-based learning problems will lead to the use of a holistic approach and therefore more profitabl e for mastery and knowledge transfer. In the subsequent development of this learning process involves a real scenario, which put the big picture for the next part of the students learned to pieces.

TABLE I. Method of Design based Learning Thematic Integrative on issue at Elementary School

\begin{tabular}{|c|c|}
\hline 4. FOURTH GRA] & \\
\hline 5. Themes List & $\begin{array}{ll}\text { 6. } & \begin{array}{l}\text { Problems } \\
\text { Concept }\end{array}\end{array}$ \\
\hline $\begin{array}{l}\text { The beauty } \\
\text { togetherness }\end{array}$ & Problems in a group \\
\hline Save energy & Energy saving problem \\
\hline $\begin{array}{l}\text { Care about the Living } \\
\text { Things }\end{array}$ & Problem of living beings \\
\hline Various Jobs & Problems of land the job \\
\hline Appreciate the hero & $\begin{array}{l}\text { Problem of attitudes the } \\
\text { heroes }\end{array}$ \\
\hline The beauty of my country & $\begin{array}{l}\text { Update problem from my } \\
\text { country }\end{array}$ \\
\hline My aspiration & Realizing ideals \\
\hline My place of purpose & Environment problems \\
\hline $\begin{array}{l}\text { Healthy and nutritious } \\
\text { food }\end{array}$ & $\begin{array}{l}\text { The problem of healthy and } \\
\text { nutritious food }\end{array}$ \\
\hline
\end{tabular}

\begin{tabular}{ll}
\hline \multicolumn{1}{c}{ 7. FIFTH GRADE } & \multicolumn{1}{c}{ 9. Themes List } \\
$\begin{array}{l}\text { Play with the objects } \\
\text { around }\end{array}$ & $\begin{array}{c}\text { Problems } \\
\text { Concept }\end{array}$ \\
Events in life & Problems in the face of life \\
Pillars living & Problems of pillar \\
$\begin{array}{l}\text { The important of health } \\
\begin{array}{l}\text { The proud as a nation } \\
\text { Indonesia }\end{array}\end{array}$ & Thealth Problems \\
\hline
\end{tabular}




\begin{tabular}{ll}
\hline Save's being living & $\begin{array}{l}\text { The problems of the } \\
\text { existence live }\end{array}$ \\
Unity in difference & Problems in a group \\
Figure and inventor & Discovery problems \\
Gobalization & Globalization problems \\
The entrepreneurial & Entreprenerial problems \\
Public health & Problems in public health \\
\hline
\end{tabular}

\section{CONCLUSION/RECOMENDATION}

\section{[1] Conclusion}

Problem-based learning is a great way to gain knowledge that combines aspects of cooperative learning and concentrating activiti es on group work skills, problem-solving and independent study, as well as finding the importance of interdisciplinary knowledge for understanding issue. Problem based learning is a learning situation in which problems become the starting point of learning.

PBM is in line with the idea of national education which brings orientation competenc ybased education. As part of the active learning method is a method of problem-based learning, the most extensive since it combines the skills of thinking, real problems and working in groups. In addition, the development of a Problem Based Learning in accordance with today's education paradigm that is integrative theme.

\begin{tabular}{|c|c|c|}
\hline $\begin{array}{l}\text { 13. Integ } \\
\text { rative }\end{array}$ & $\begin{array}{l}\text { 14. Thema } \\
\text { tic }\end{array}$ & $\begin{array}{ll}\text { 15. } & \text { Probl } \\
\text { em } \\
\text { Based } \\
\text { Learn } \\
\text { ing }\end{array}$ \\
\hline $\begin{array}{l}\text { TABLE XVII. } \\
\text { ased on student } \\
\text { centered }\end{array}$ & $\begin{array}{l}\text { TABLE XVIII. } \\
\text { ased on student } \\
\text { centered }\end{array}$ & $\begin{array}{l}\text { TABLE XIX. } \\
\text { ased on student } \\
\text { centered }\end{array}$ \\
\hline $\begin{array}{l}\text { TABLE XX. } \\
\text { ive to } \\
\text { student experien } \\
\text { ce Provide }\end{array}$ & $\begin{array}{l}\text { TABLE XXI. } \\
\text { ive to } \\
\text { student experience } \\
\text { Provide }\end{array}$ & $\begin{array}{l}\text { TABLE XXII. } \\
\text { ive to } \\
\text { student experien } \\
\text { ce Provide }\end{array}$ \\
\hline $\begin{array}{l}\text { TABLE XXIII. } \\
\text { he learning } \\
\text { aktifity }\end{array}$ & $\begin{array}{l}\text { TABLE XXIV. } \\
\text { leksibility }\end{array}$ & $\begin{array}{l}\text { TABLE XXV. } \\
\text { earning focus }\end{array}$ \\
\hline $\begin{array}{l}\text { TABLE XXVI. } \\
\text { earning the need } \\
\text { of student }\end{array}$ & $\begin{array}{l}\text { TABLE XXVII. } \\
\text { earning the need } \\
\text { of student }\end{array}$ & $\begin{array}{l}\text { TABLE XXVIII. } \\
\text { nterest of student }\end{array}$ \\
\hline $\begin{array}{l}\text { TABLE XXIX. } \\
\text { hole learning }\end{array}$ & $\begin{array}{l}\text { TABLE XXX. } \\
\text { earning while } \\
\text { playing }\end{array}$ & $\begin{array}{l}\text { 1. TABLE XXXI. } \\
\text { earning while } \\
\text { playing }\end{array}$ \\
\hline
\end{tabular}

When we look at the matrix above, then we can know that between integrative approach, thematic, problem-based learning, and have the same characteristics, so that the same characteristics with it's possible when on done the problem possible when done on the problem-based learning, thematic learning integrative in elementary school. The development of problem-based

learning on integrative thematic is a method to provide experience to students in learning through a contextual probl ems that would be expected to provide student with many solutions based to each theme.

The link between such methods can be described in the following matrix.

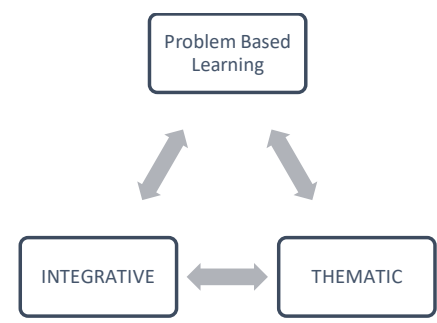


It can be concluded that between integrative approach, thematic, problem based learning, and have the same characteristics, so that with it's possible whwn done on the problem based learning, thematic integrative in elementary school. The development of problem-based learning on integrative thematic is a method to provide experience to

students in learning through a contextual $\mathrm{p}$ roblems that would be expected to provide students with many solutions based to each theme.

\section{REFERENCES (Examples)}

Ismaimuza, D. (2010). Kemampuan Berpikir Kritis dan Kreatif Matematis Siswa SMP melalui Pembelajaran Berbasis Masalah dengan Strategi Konflik Kognitif. Disertasi pada PPs UPI. Bandung: Tidak Diterbitkkan.

Lang. R.H. and David N. Evans (2006) Models, Strategy and Methods for Effective Teaching Pearson A\&B Boston New York San Fransisco.

Overbaugh Richard C (2005) Problem Based Learning and Fourth Grade Who Really Benefits old Dominion University The Constructivist fall 2005 Vol 16 No 1 ISSN 1091-4072.

Rau, Dar-Chin dkk (2004) Four Phase to Construct Problem Based Learning instruction Materials International Confrence on Enginering Education October 16-21,2004, Gainessvile Florida. 